\title{
PRZED WOJNĄ. PEDAGOGICZNE IDEE, OPINIE, POGLĄDY W WYBRANYCH CZASOPISMACH POLSKICH Z 1939 ROKU
}

\author{
Before the War. Pedagogical Ideas, Opinions and Views in Selected \\ Polish Magazines of 1939.
}

Summary: The subject of the article is the content of selected Polish magazines depicting the views on the educational ideals, the part of tradition in their development, as well as new trends in pedagogy dominating in those times. They originate in various research areas, such as 'Filomata' of Lviv, disseminating the deepened knowledge of the classical tradition in Poland, 'Pedagogium,' 'the magazine devoted to the psychology of a teacher and methods of educating,' 'Pełnia życia' ('The Fullness of Life'), a quarterly for monks, or 'Parametr,' a specialist journal on teaching mathematics, including more general reflections can be found on the obligations imposed on teachers in that time. The key of the selection is 1939, the time of the edition of all the texts mentioned above and the connection, mediate or immediate, with the events which were soon to change radically the picture of Europe and of the world.

Keywords: cultural watershed, war as the turning point, educational ideal, psychology and pedagogy, the part of the classical tradition in education

${ }^{1}$ Dr hab. Wiesława Sajdek, prof. AJD w Częstochowie - kierownik Zakładu Historii Filozofii w Instytucie Filozofii Wydziału Filologiczno-Historycznego Akademii im. Jana Długosza w Częstochowie. Adres: Zakład Historii Filozofii AJD, ul. Waszyngtona 4/8, 42-200 Częstochowa; e-mail: wsajdek@gmail.com. 


\section{Wstęp}

Tytuł tego artykułu koniecznie wymaga ścisłego dookreślenia czasowego, inaczej mógłby ktoś zapytać: „ale przed którą wojną?”. Pytanie to poniekąd zdradza młody (lub względnie młody) wiek pytającego. Jeszcze dla mojego pokolenia - studiujących $\mathrm{w}$ drugiej połowie lat siedemdziesiątych oraz na początku lat osiemdziesiątych ubiegłego stulecia - „przed wojną” oznaczało jednoznacznie: „przed drugą wojną światową". Dystans czasowy, który dzieli nas od tamtych czasów przedwojennych, pozwala zobaczyć wyraźniej dzisiaj, to jest po koniec drugiego dziesięciolecia XXI wieku, różnice kulturowe, jakie występowały już wcześniej, ale jeszcze w latach siedemdziesiątych nie były one tak oczywiste i nie wydawały się nam, wtedy studiującym, tak drastyczne. Byliśmy wychowywani - mam na myśli sferę publiczną - wedle innego niż przed wojną paradygmatu, inne stały za tym idee i poglądy. Dzisiaj staje się coraz bardziej jasne to, że te różnice są o wiele głębsze niż „tylko” ustrojowe czy ideologiczne i dotyczą wymagań odnoszących się do najgłębszych pokładów człowieczeństwa. To nie „kapitalizm” albo „socjalizm” narzuca określone ideały, a inne deprecjonuje - u podstaw zmian o zasięgu kulturowym wydaje się bowiem leżeć określona filozofia człowieka, która wyraża się w takich lub innych filozofiach polityki oraz pedagogiki. To filozofia człowieka skłania do akceptacji bądź negacji pewnych form i przekształceń ustrojowych, a także określonych pedagogicznych zasad i nabudowanych na nich doktryn. Co zaś wpływa na kształt tej filozofii? Otóż kształtowana jest ona przez dzieje człowieka, historię powszechną ludzkości, historię kultury, a więc także pamięć dotyczącą tej historii i wreszcie refleksję nad tym, co jest przechowywane w skarbcu pamięci.

Scripta manent - na szczęście zachowało się wiele czasopism, być może wszystkie z interesującego nas tutaj przedmiotu, które ukazały się od początku pierwszego i prawie do końca trzeciego kwartału „roku pamiętnego”, przed 1 września 1939 roku. Wychodziły wtedy takie czasopisma wielonakładowe o treści pedagogicznej, jak „Oświata i Wychowanie” czy też „Ruch Pedagogiczny” (ostatni numer „Kwartalnika Pedagogicznego” ukazał się w roku 1938, podobnie jak numer „Rocznika Pedagogicznego”, redagowanego przez Samuela Dicksteina). Na temat profilu czasopisma „Oświata i Wychowanie” pisała w „Studiach Pedagogicznych Akademii Świętokrzyskiej” Teresa Gumuła:

W artykule wstępnym pierwszego numeru „Oświaty i Wychowania” nakreślono profil czasopisma, które miało być poświęcone w całości zagadnieniom oświatowo-wychowawczym w zakresie odpowiadającym działalności ministerstwa. Treść czasopisma miały stanowić zagadnienia „kultury duchowej” społeczeństwa, adresatem mieli być

2 „Ruch Pedagogiczny”, którego rocznik 28 sygnowany jest na rok 1938/1939, zyskał kontynuację już w roku 1945/1946 jako rocznik 29. 
nauczyciele, wychowawcy, działacze oświatowi oraz wszyscy, którym leżało na sercu kształcenie i wychowanie młodzieży. Komitet Redakcyjny zamierzał prowadzić dyskusję z czytelnikami, krzewić wiadomości o szkole i sprawach wychowawczo-kulturalnych. Zakładano, że w toku wymiany poglądów i opinii wyłoni się ideał wychowawczy, odpowiadający wymaganiom życia prywatnego, społecznego i państwowego, który mógłby służyć jako drogowskaz w pracy wychowawczej³

Ideał ów wyznaczał zespół celów wychowawczych, natomiast „Cele wychowawcze były ściśle związane z życiem narodu”, a „nauczanie powinno mieć cel wychowujący".

Jeśli mowa o „ideale wychowawczym”, to wypada dookreślić samo pojęcie pedagogiki, tutaj używane ${ }^{5}$. Otóż w tym szkicu jest ona rozumiana w jak najściślejszym związku z wychowaniem człowieka, jako refleksja o wychowaniu, a dopiero przy tej okazji o wykształceniu, będącym jego istotnym elementem: „[...] może być wreszcie pedagogika refleksją o wychowaniu, w której dominującym ujęciem byłaby hermeneutyka"6. Sławomir Sztobryn podkreśla związek tak rozumianej pedagogiki z filozofią człowieka, ponieważ „[...] pozwala widzieć istotę owej dyscypliny w twórczym namyśle, oscylacji, interpretacji różnorodnych myśli dotyczących kondycji człowieka jako istoty godnej wychowania"7.

W hermeneutyce istotnym zabiegiem jest świadomość momentu czasowego, a zarazem miejsca w kulturze, punktu, do którego ona doszła i z którego patrzymy na pewien wybrany wycinek minionego czasu. Stąd kilka refleksji na ten temat, zamieszczonych na początku „Wstępu”.

Kilka przedstawionych poniżej idei i poglądów pedagogicznych, które znalazły się $\mathrm{w}$ tuż przed wojną wydanych periodykach, dotyczy różnych dyscyplin naukowych oraz obszarów kształcenia, związanych z różnymi przejawami kultury.

3 Teresa Gumuła, „Zadania wychowawcze szkoły na łamach czasopisma »Oświata i Wychowanie« (1929-1939)”. Studia Pedagogiczne Akademii Świętokrzyskiej 15 (2005): 185. Według klasyfikacji Jerzego Jarowieckiego czasopismo „Oświata i Wychowanie” mieści się w grupie „czasopisma urzędowe", jako że przedstawia problemy widziane z perspektywy ówczesnego ministerstwa. Jerzy Jarowiecki, hasło „Czasopisma pedagogiczne w Polsce”, w: Encyklopedia pedagogiczna, red. Wojciech Pomykało (Warszawa: Fundacja „Innowacja” 1993), 83.

4 Tamże, 188.

5 Tadeusz Lewowicki, „Pedagogika a demokracja - refleksje nad kondycją pedagogiki”, w: Demokracja a oświata, kształcenie i wychowanie. Materiały z II Ogólnopolskiego Zjazdu Pedagogicznego, red. Henryka Kwiatkowska, Zbigniew Kwieciński (Toruń: Polskie Towarzystwo Pedagogiczne 1996), 34. Jedno z kilku omówionych tam znaczeń pojęcia „pedagogika” oznacza refleksję o wychowaniu.

"Sławomir Sztobryn, „Wstęp”, w: tegoż, Polskie badania nad myśla pedagogiczna w latach 1900-1939 w świetle czasopiśmiennictwa. Ujęcie metahistoryczne (Łódź: Wydawnictwo Uniwersytetu Łódzkiego 2000), 7.

7 Tamże. 
Nie stanowią one w sposób wyczerpujący „dowodu” żadnej spójnej tezy, ale też nie ma w nich niczego niekoherentnego w kontekście pewnej określonej filozofii człowieka. Jak odłamki rozbitego lustra wydają się odbijać, wprawdzie fragmentarycznie i niepełnie, tę samą rzeczywistość - pewien ideał człowieka i człowieczeństwa, który można by nazwać „przedwojennym”. Wchodzi weń zarówno zaangażowanie psychologii $\mathrm{w}$ wychowywanie przyszłych nauczycieli, spójny ideał „wykształcenia”, mający stanowić podstawę dla racjonalnie uzasadnionego światopoglądu, jak i rozumna miłość „aż do śmierci” jako ideał wypracowany w środowiskach osób żyjących we wspólnotach zakonnych oraz - co może w pierwszym momencie zdumiewać - ideały wychowawcze zaczerpnięte $\mathrm{z}$ odległych epok pogańskiego antyku.

To, co podzielone w obszarze kształcenia, wywiera swój komplementarny wpływ na ucznia lub człowieka już ukształtowanego, dorosłego, a także powinno stanowić przemyślany i spójny konglomerat wiedzy i poglądów. Dotyczy to zarówno programów nauczania, jak i sposobów, w jaki jest realizowany. Z tych oczywistych wymogów zdawano sobie sprawę już wtedy, o czym świadczą niektóre z przytoczonych poniżej wypowiedzi. Z pewnością najważniejszy był tutaj ideał człowieka, ku któremu miało prowadzić i wykształcenie, i całościowe wychowanie. Wzór ten stawał się, jeśli nie głównym przedmiotem, to z pewnością istotnym tłem wszelkich uprzednich refleksji wobec odpowiedzi na pytanie, jak należałoby postępować, aby się do niego upodobnić.

Psychologia jako nauka pomocnicza w przedwojennej pedagogice na przykładzie „Pedagogium. Czasopisma poświęconego psychologii nauczyciela i sposobom jego kształcenia”, red. Jan Schwarz

Tuż przed wojną żywe były w ówczesnych czasopismach pedagogicznych treści psychologiczne. Zastanawiano się nie tylko nad tym, w jaki sposób można rzetelnie badać i oceniać, a następnie stymulować naturalne zdolności i zainteresowania wychowanków, lecz także nad tym, jak wychowywać i kształcić do swych przyszłych zajęć pedagogów. Wzniosłe hasła i konkretne badania empiryczne, wszelkie uprzednie przygotowania były następnie konfrontowane $\mathrm{z}$ wcale niełatwą ówczesną rzeczywistością szkolną. W jednym z tekstów opublikowanych tuż przed wojną w toruńskim periodyku Stanisław Nowaczyk zauważył:

Praca nauczyciela nie należała nigdy do zajęć łatwych, obecnie jednak staje się coraz trudniejsza: przeludnienie klas, brak izb lekcyjnych, konieczność realizowania nowych i niewypróbowanych dotychczas w sposób naukowy programów, częste zmiany podręczników, niskie uposażenie i wynikająca stąd potrzeba zajęć dodatkowych - oto powody najważniejsze. [...] Utrudnieniem jest również nadmiar haseł, o których mówi się chętnie przy każdej okazji a często bez widocznej potrzeby: praca twórcza, środowisko, indywidualizacja, regionalizm itd.[...] Słuszne jest spostrzeżenie 
Nawroczyńskiego, że obok starych szablonów, które nazywamy rutyną, istnieją również szablony goniących za modą płytkich nowatorów szkolnych ${ }^{8}$.

Przynajmniej niektóre z wymienionych wtedy zastrzeżeń i trudności, niestety, i dzisiaj nie straciły w niczym na aktualności.

Efemeryczny był los tego periodyku toruńskiego, o tytule „Pedeagogium”, z podtytułem: „Czasopismo poświęcone psychologii nauczyciela i sposobom jego kształcenia” (red. Jan Schwarz). Jego drugi i ostatni numer ukazał się w 1939 roku. Pismo będące półrocznikiem za swój przedmiot przyjęło psychologię, wokół której toczyły się wówczas żywe dyskusje w kontekście tego, jaką rolę ma ona odegrać w nowoczesnej pedagogice. W obszernym artykule jego autor - a zarazem redaktor - zastanawia się nad możliwością wykształcenia pozytywnych cech u osób mających pełnić w życiu zawodowym pedagogiczne funkcje, czy raczej realizować swoje życiowe powołanie w zawodzie nauczyciela. Tak czy inaczej pewne zalążki pożądanych cech przyszli pedagodzy posiadają dzięki dziedziczeniu i pytanie dotyczy tego, co i w jakim stopniu można w związku z tym u nich wzmocnić, albo nawet od początku ukształtować. Jako cechy dobrego pedagoga wymieniono między innymi życzliwość i łatwość nawiązywania z młodzieżą kontaktu, empatię, takt oraz „planowość i wytrwałość w pracy nad młodzieżą”. W zaprezentowanym materiale znalazły się wyniki badań empirycznych nad kształtowaniem jednej wybranej cechy przyszłego nauczyciela, jaką miał być dar obserwacji dzieci i oceny stopnia ich zdolności. Niezależnie od przedstawionych wyników badań i stopnia możliwości ich wykorzystania dzisiaj trzeba zauważyć, że zasada: nauczycielu, pracuj nad swoim charakterem oraz umiejętnościami pedagogicznymi, zanim zaczniesz pracować nad młodzieżą, a i wtedy także nie ustawaj w tej pracy nad sobą, jest tyleż logiczna, co ponadczasowa.

\section{O konieczności spójnej hierarchii celów wychowawczych w pedagogice - od matematyki do filozofii}

Czasopismo przedwojenne „Parametr” adresowane było do nauczycieli matematyki. Skupiało zasadniczo teksty dotyczące nauczania tego przedmiotu, dzielenie się doświadczeniami oraz omawianie nowości w tej dziedzinie. A jednak matematyka, przez swój charakter, a także metody jej nauczania, może dostarczać inspiracji innym obszarom dydaktycznym. Autorka niewielkiej rozprawki „O celu lekcji” ${ }^{10}$ wyjaśnia związek między „zadaniem” lekcji, które ma być

${ }^{8}$ Stanisław Nowaczyk, „Rola nauczycielstwa w naukowym organizowaniu pracy szkolnej (Materiały do dyskusyj i referatów)", Pedagogium. Czasopismo poświęcone psychologii nauczyciela i sposobom jego kształcenia, red. Jan Schwarz, 2 (1939): 118. Autor powołał się na pracę Bogdana Nawroczyńskiego, Zasady nauczania (Lwów-Warszawa: Książnica Atlas, 1930), 380.

${ }^{9}$ Nowaczyk, „Rola”, 120.

10 Była nią dr Ludwika Jeleńska z Poznania - Parametr 3, 1 (styczeń 1939): 1-3. 
podporządkowane w sposób jasny i wyraźny wyższemu celowi - tematowi bardziej ogólnemu. Ten zaś temat wpisany jest w cały łańcuch celów, a: „Wszystkie one są środkami do celu głównego - wykształcenia”. Doskonała harmonia tak uporządkowanego programu nauczania matematyki, „królowej nauk”, przypomina o możliwości i potrzebie wzorowania się na matematyce w układaniu programów innych dyscyplin. Nasze poznanie, aby mogło stanowić przejrzystą oraz sensowną całość, musi być uporządkowane - porządek zaś opiera się na hierarchii celów i zadań. Pewne wybrane cele są po prostu najważniejsze. Przejrzysta hierarchia zadań i celów, którą najłatwiej uchwycić przy nauczaniu matematyki, stanowi ważną wskazówkę metodyczną ogólnej natury. Koniec końców „wykształcenie” powinno oznaczać opanowanie programu, którego elementy są ze sobą logicznie powiązane, w hierarchicznie ułożonym porządku celów. Taki porządek zakłada uprzednie ustalenia co do głównego celu wykształcenia, a jeśli tak, to wymaga głębokiego namysłu o charakterze aksjologicznym i jeszcze raz świadczy o konieczności ścisłych związków między pedagogiką a filozofią.

W numerze kwartalnika o treści filozoficznej „Przegląd Filozoficzny” (Warszawa, 1 V 1939 roku) przy końcu zamieszczono kilka „Sprawozdań z książek” taki nagłówek nosił ten dział. Henryk Elzenberg w niewielkiej notatce polecał tam nowe wówczas opracowanie filozofii greckiej, którego autorem był prof. Karol Werner z Genewy. Książka wydana w 1938 roku w Paryżu (La philosophie grecque $)^{11}$ napisana była w języku francuskim, który nie stanowił wówczas żadnej bariery dla osoby wykształconej. Elzenberg zauważył:

Autor [tj. K. Werner -W.S.] zdaje się przychylać do koncepcji, według której filozofia ma być nie tylko wyjaśnieniem, ale i u sprawiedliwien iem świata, pracą nad skonstruowaniem takiego, niesprzecznego z doświadczeniem, jego obrazu, przy którym wydałby się on człowiekowi sensownym ${ }^{12}$.

Elzenberg konstatuje, że: „Na dnie myśli prof. Wernera zdaje się jednak tkwić [...] pewien dogmatyczny optymizm, przekonanie, że świat jest »rzeczywiście« sensowny i że filozofia, która go usprawiedliwia, jest jedyną filozofią "prawdziwą" "13. Chociaż Elzenberg wykazuje niejaki sceptycyzm wobec tak optymistycznego stanowiska, słusznie wiąże je z filozofią klasyczną, a książkę poleca jako „znakomitą pomoc dla studiujących”" ${ }^{2}$. Zapewne i dzisiaj miałaby ona swój walor, zwłaszcza w świetle opinii niedawno zmarłego prof. Giovanni Reale

${ }^{11}$ Książka ta została wydana ponownie wiele lat po wojnie, w tym samym paryskim wydawnictwie (Paris: Payot 1962).

12 Przegląd Filozoficzny 42, 1 (1939): 110.

13 Tamże.

14 Tamże, 111. 
z Mediolanu, który myśl starożytną proponował dzisiejszemu światu jako lekarstwo na nihilizm przeżerający współczesną powojenną kulturę ${ }^{15}$.

Niemniej ciekawa z naszego punktu widzenia jest kolejna pozycja, omówiona w tym samym numerze „Przeglądu Filozoficznego” w dziale sprawozdań. Tadeusz Juliusz Kroński napisał o książce wydanej w Pradze, w 1938 roku pod dość enigmatycznym tytułem Nauka i duch, której autorem był Jan B. Kozák, profesor filozofii na praskim Uniwersytecie Karola. Tadeusz Juliusz Kroński pisze, że jest ona „próbą wykazania, że naturalizm manifestujący się także i w polityce jest groźny i szkodliwy dla ludzkości”"16. W ówczesnej Europie - pisał prof. Kozák - triumf święciła „reakcja przeciw duchowi” ${ }^{17}$ obecna zarówno w nauce, jak i w polityce właśnie jako przejawy naturalizmu. Wyrażał się on „w postaci komunizmu i materialistycznie ufundowanego nacjonalizmu” ${ }^{18}$. Istotą naturalizmu jest wedle Kozáka: „pasywizm, rozumiany jako tendencja do ujmowania człowieka jako części przyrody”'19. Istnieje w związku z tym niebezpieczeństwo „odczłowieczenia pojęcia człowieka” - „człowiek współczesny uwierzył, że jest zwierzęciem”20. Kierunkiem, który walczy z podobnymi konkluzjami, jest, zdaniem Kozáka, fenomenologia, a człowiek różni się od zwierzęcia duchem. „Ludzkość ustępuje brutalności, gdy tylko zatraci pojęcie człowieczeństwa" - ostrzegał tuż przed wojną profesor z Pragi ${ }^{21}$.

Uczeni uprawiający pedagogikę teoretyczną, a także liczni praktycy w swoich założeniach pedagogicznych opierali się i opierają mniej lub bardziej świadomie na określonej filozofii. Ale uznany i jakoś uzasadniany na jej gruncie system wartości wymaga również sankcji innego rodzaju, zwłaszcza jeśli nadaje się im rangę absolutną. We współczesnym tekście pt. „Aksjologiczne podstawy katolickich koncepcji pedagogicznych" czytamy:

[...] należy zauważyć, że koncepcje pedagogiczne z reguły zakorzeniając się $\mathrm{w}$ konkretnej filozofii, najczęściej osadzają się także w jakiejś religii (na przykład w koncepcji Marii Montessori religia odgrywała niezmiernie istotną rolę, rozważania o człowieku Emmanuela Levinasa także mają aspekty religijne, chociaż nie katolickie) - co nie zawsze bywa przedmiotem uwagi pedagogów w kwestii istotności religii dla wychowania ${ }^{22}$.

${ }^{15}$ Giovanni Reale, „Mądrość antyczna lekarstwem na zło nękające współczesnego człowieka”, w: Giovanni Reale, Doktor Honoris causa Katolickiego Uniwersytetu Lubelskiego, red. Agnieszka Bieńkowska (Lublin: Wydawnictwo KUL 2001), 13-41.

16 Tadeusz Juliusz Kroński, „Sprawozdania z książek”, Przegląd Filozoficzny 42, 1 (1939): 111.

17 Tamże.

18 Tamże.

19 Tamże.

${ }^{20}$ Tamże. Oba ujęte w tym zdaniu w cudzysłowy określenia są cytatami z tekstu prof. Kozáka, które przytacza Kroński w swoim omówieniu.

${ }^{21}$ Tamże.

22 Janina Kostkiewicz, „Aksjologiczne podstawy katolickich koncepcji pedagogicznych”, w: Chrześcijańskie inspiracje w pedagogice, red. Janina Kostkiewicz (Kraków: Wydawnictwo Uniwersytetu Jagiellońskiego 2011), 14-15. 
Dlatego wybór kolejnego przedwojennego periodyku wydaje się w pełni uzasadniony.

\section{Wychowanie do pełni człowieczeństwa w perspektywie katolickiej}

Pierwszy i bodaj ostatni numer kwartalnika „Pełnia Życia”, wydany przez OO. Redemptorystów w Tuchowie, ukazał się w styczniu 1939 roku $^{23}$. Przeznaczony był dla osób zakonnych, a zwłaszcza dla zakonnic. Można by rzec, że stworzenie profilu czasopisma, skierowanego do tak wąskiej oraz wyjątkowej grupy osób niewiele może nam powiedzieć o pedagogicznych ideach, jakie wówczas oddziaływały $\mathrm{w}$ polskim społeczeństwie. A jednak należy się spodziewać, że rodzaj formacji, którą otrzymywały ówczesne zakonnice, był następnie przez nie przekazywany w licznych, prowadzonych przez nie wtedy ośrodkach szkolnych i wychowawczych, a także w niemniej licznych ośrodkach pozaszkolnych. Statystyki z tym związane mówią same za siebie i są naprawdę imponujące. W omawianym numerze w artykule „Polskie zakony żeńskie w świetle liczb", umieszczona została informacja, że zakonnice prowadziły wtedy 228 „szkół powszechnych”, do których uczęszczało 29609 dzieci, 46 gimnazjów, w których uczyło się 8013 uczennic, a także 99 szkoły zawodowe z 4064 uczennicami. Organizowały oraz angażowały się nie mniej intensywnie w oświatę pozaszkolną, prowadząc liczne kursy dokształcające, roczne, półroczne, trzymiesięczne oraz kilkutygodniowe ${ }^{24}$. Pracowały w organizowanych przez zakony żłobkach, przedszkolach, sierocińcach, internatach, a nawet domach poprawczych. Angażowały się z ogromnym poświęceniem przy opiece nad chorymi w szpitalach, zajmowały się dokarmianiem najuboższych, przygotowując posiłki w specjalnych kuchniach dla ubogich, pracowały w "przytuliskach dla służby", świetlicach i domach noclegowych. Nie zostały tutaj wymienione wszystkie obszary oraz formy zaangażowania sióstr zakonnych w życie społeczne, ale już ze względu na powyższe informacje warto przypomnieć przynajmniej wybrane zasady, którymi kierowały się zakonnice i które usiłowały zaszczepić swoim wychowankom i podopiecznym słowem i przykładem.

$\mathrm{Na}$ pierwszym miejscu w „Pełni Życia” stawiano artykuły o treści ascetycznej dotyczące życia wewnętrznego. Najpierw formacja duchowa. Budować ją miały przykłady życiorysów osób uznanych, a także te, dostarczane w listach, wspomnienia osób najbliższych, znanych dotychczas tylko rodzinie. Podobną funkcję miały spełnić nawiązania do historii, w tym wypadku do historii klasztorów, wplecionej w dzieje Rzeczpospolitej. Pismo zawiera

${ }^{23}$ W Bibliotece Jagiellońskiej jest dostępny jedynie ten numer.

${ }^{24}$ Por. przyp. 1 na 67 s. omawianego numeru Petni Życia: wszystkie przytoczone w artykule (oraz powyżej) dane liczbowe pochodzą z dwóch źródeł: Rocznik statystyczny Kościoła katolickiego w Polsce (Lublin: Uniwersytet 1938) oraz Zakony żeńskie w Polsce, autorstwa o. Mariana Pirożyńskiego (Lublin: Uniwersytet 1935). 
ciekawe fragmenty kroniki benedyktynek z klasztoru w Grudziądzu, obejmujące ponad sto lat (od 1631 do 1734 roku). Były to czasy bardzo niespokojne, pełne wojen i przewrotów, a do tego dochodziły klęski żywiołowe i rozliczne wypadki losowe, pomimo których zakonnice ofiarnie żyły i pracowały, w pełni świadome tego, że trudności i doświadczenia przyjść muszą. Inny tekst przypomina dzieje karmelitanek z Wilna, które były tam od 1638 roku, a w 1863 roku, ,jako ofiary powstania [styczniowego - W.S.] złożyły wszystko na ołtarzu ojczyzny”. Od grudnia 1938 roku kilka karmelitanek znowu zamieszkało w Wilnie. „Wielkie jest zadanie Karmelu w Wilnie, na wschodniej rubieży Rzeczypospolitej, gdzie ledwo kilka mil dzieli od kraju bezbożniczego, skąd jak z kłębowiska żmij, wydziela się trucizna zabójcza na świat cały” - pisał ówczesny „Głos Karmelu”, we fragmencie przytoczonym przez redaktorów „Pełni Życia” ${ }^{25}$.

W tym samym numerze przywołane zostały też słowa papieża skierowane do zakonów (podczas audiencji członków kapituły generalnej OO. Kapucynów w Rzymie, w czerwcu 1938 roku). Otóż Ojciec św. nawoływał zakony do surowości - a słowa te redaktor kwartalnika opatrzył następującym komentarzem: „[...] albowiem tylko surowość może zadowolić prawdziwą miłość, godną przyjaciół Chrystusownych - zwłaszcza owa surowość, kiedy idzie o karność w zakonie, w rodzinach, w każdym domu. Karność jedynie podtrzymuje bujność życia, bez niej życie może trwać, lecz z trudem, słabe i nieudolne"26. Zwłaszcza że, jak zauważa komentator: „[...] w atmosferze naszych czasów unosi się tyle niezdrowych zasad bezkarności i niezależności!"27. Obraz ówczesnej rzeczywistości społecznej w ogóle nie napawał optymizmem, w perspektywie osób współtworzących nowo powstały periodyk:

Walka wre zawzięta o największe wartości życia; zawziętsza niż kiedykolwiek. Nienawiść wrogów Chrystusa nie pozwala im zmrużyć oka. Wszelkich chwytają się środków, byle tylko imię Boże wymazać z ziemi żyjących. Wciskają się wszędzie, wszystkiego próbują. Opanowali kina, teatry, posługują się radiem; najpotężniejszą śmiertelną ich bronią w ręku zła prasa. Przy pomocy piśmiennictwa - złych książek, gazet, czasopism, szerzą swe idee wrogie Kościołowi i Bogu, ośmieszają świętości religijne, sieją nienawiść i zgorszenie ${ }^{28}$.

Kolejny tekst „Zakony wobec Akcji Katolickiej” także wskazuje na zagrożenia związane $\mathrm{z}$ wychowaniem młodzieży, za bodaj największe $\mathrm{z}$ nich uważając propagandę komunistyczną: „[...] zakonnicy podtrzymują swe chwalebne tradycje w szlachetnej gotowości niesienia pomocy zagrożonym duszom, [...] w tej

\footnotetext{
${ }^{25}$ Petnia Życia, 87.

26 Tamże, 56-57.

27 Tamże, 57.

${ }^{28}$ Tamże, 7 - „Myśl nasza” (redakcyjny „wstępniak”).
} 
chwili tak trudnej, dla ratowania młodzieży, osaczonej przez tylu nieprzyjaciół, a zwłaszcza przez propagandę komunizmu"29.

$\mathrm{Na}$ samym początku omawianego numeru $\mathrm{w}$ zamieszczonej tam modlitwie, zatytułowanej „Z błogosławieństwem Matki”, pojawia się prośba o „przymnożenie miłości silnej jako śmierć, ofiarnej i apostolskiej, miłości zwycięskiej”. Wokół pojęcia miłości panował wówczas zupełnie inny, pełen powagi klimat, tak że łączenie postawy pełnej ofiarnej miłości z właściwymi relacjami społecznymi, a zwłaszcza tymi, które wiązały się z wychowaniem dzieci i młodzieży, stawało się w pełni uzasadnione. $\mathrm{W}$ innym miejscu umieszczona została formuła modlitwy o miłość, która ma być również „rozumna i cierpliwa” ${ }^{30}$. Przy końcu czasopisma umieszczona została prośba redakcji dotycząca przesyłania książek i artykułów o treści „religijnej i wychowawczej”. W tym klimacie bowiem oba te wymiary przenikały się nawzajem i wspierały.

Przejmująco brzmią dzisiaj banalne wówczas uwagi o wydarzeniach, które nastąpiły „po wojnie”, po roku 1918. Zwłaszcza wobec perspektyw programowych pisma i jego planowanego rozwoju w najbliższej przyszłości.

Pismo „Pełnia Życia” nie było z założenia periodykiem o treściach pedagogicznych. A jednak profil człowieka, który wyłania się z licznych konkretnych przykładów i uwag na temat wewnętrznej doskonałości, konieczności pracy nad własnym wnętrzem, wymóg ofiarnej pracy i wierności aż do śmierci przyjętym ideałom - to wszystko stanowi wyraźny pedagogiczny ideał. I chociaż nie ma w nim także odniesień i dyskusji ściśle politycznych, to zachowania tak licznych osób duchownych, tak wielu księży, braci zakonnych i zakonnic podczas wojny, która zostanie rozpętana już jesienią 1939 roku, stają się w świetle przedstawionego tutaj ideału przede wszystkim zdumiewająco konsekwentne, a ich życiorysy stanowią niezwykły dowód na to, że ideał ów jest możliwy do zrealizowania. Był on związany niewątpliwie z pedagogiką o korzeniach katolickich. Janina Kostkiewicz, omawiając problemy dyskutowane na gruncie pedagogiki katolickiej lat 1918-1939, zauważa:

[...] w Polsce ważne było jeszcze jedno: kierunek rozwoju dziejów Europy i świata wyznaczony przez promowane ideologie, a w nich nowe wizje człowieka i jego wychowania. Ten ostatni czynnik wywołał żywą reakcję na gruncie pedagogiki katolickiej. [...] (by odpowiednio odzwierciedlić dyskursywno-krytyczny kierunek rozwoju pedagogiki katolickiej, należy stwierdzić, że najradykalniejsza krytyka była kierowana ku wizjom człowieka i praktyce jego wychowania w sowieckim bolszewizmie, niemieckim narodowym socjalizmie i włoskim faszyzmie) ${ }^{31}$.

29 Tamże, 62. Jest to fragment listu kardynała Eugenio Pacelliego, sekretarza stanu Piusa XI, do przełożonych zakonnych.

30 Tamże, 64.

${ }^{31}$ Janina Kostkiewicz, Kierunki i koncepcje pedagogiki katolickiej w Polsce 1918-1939 (Kraków: Oficyna Wydawnicza „Impuls” 2013), 643 (z „Zakończenia”). 


\section{Antyczne wzory i ideały wychowawcze na przykładzie lwowskiego „Filomaty”}

Twórcy wydawanego we Lwowie „Filomaty”, czasopisma poświęconego kulturze antycznej, na okładce numeru z roku 1939 umieścili nie przez przypadek nagrobek rzymskiego jeźdźca. U jego stóp leży pokonany Germanin, a komentarz dołączony do rzeźby poucza, że „przedstawienie ma charakter symboliczny i przypomina obraz walki św. Michała lub św. Jerzego ze smokiem" ${ }^{32}$. Inny fragment komentarza nawiązuje wprost do sytuacji politycznej: „Nagrobek ten i setki mu podobnych miały za cel rozsławić czyny oręża rzymskiego i w ten sposób wzmocnić zwartość i gotowość obywateli wobec niebezpieczeństwa, jakim Germanie [...] grozili imperium rzymskiemu, a tym samym cywilizacji europejskiej"33. Odwoływanie się do określonych momentów historii oraz postaci starożytnej Grecji i Rzymu, jako czytelnych wzorów postępowania, stanowiło trwały zabieg wychowawczy przedwojennej pedagogiki. Niestety, propaganda hitlerowska także usiłowała zawłaszczyć rzymskimi symbolami oraz hasłami „obrony cywilizacji”.

W artykule „Honor i Ojczyzna” Ryszard Ganszyniec, odwołując się do przełomowych momentów historii Polski - bitwa z Tatarami pod Legnicą, wiktoria Sobieskiego pod Wiedniem, zwycięstwo (sprzed 20 zaledwie lat) nad bolszewikami pod Warszawą - wzywa do przeciwstawienia się

w obronie swego honoru i swych granic barbarii imperialistycznej, która w swej bucie, nie szanując ni praw, ni traktatów, ni bytu, ni wolności innych narodów, wszystkich stara się zepchnąć do roli helotów, a szczególnie nas Słowian, których w myśl swej obłędnej teorii rasistowskiej uważa za intelektualnie i etycznie mniej wartościowych, pragnie wytępić, wynarodowić, użyć jako siły roboczej, tak jak w starożytności używano niewolników, a zagrabić nasz dorobek i naszą ziemię ${ }^{34}$.

„Niewątpliwie potęga najeźdźcy jest olbrzymia: ale nie mniejsza jest wiara w słuszność naszej sprawy [... $]^{35}-\mathrm{w}$ oratorskim porywie autor wykorzystuje dobrze znane w starożytności zwroty, kiedy to osamotniona Hellada stawiała skuteczny opór potędze Persów. „Filomata” był kwartalnikiem na znakomitym poziomie, umieszczano w nim między innymi wybrane tłumaczenia z łaciny, które były plonem pracy uczniów szkół średnich, doskonale dobrane i opracowane teksty na temat wybranych elementów starożytnej kultury, a wszystko to służyć miało wychowaniu młodych „Filomatów”.

\footnotetext{
${ }^{32}$ Filomata 107 (1939), Lwów 1939, 434.

33 Tamże.

${ }^{34}$ Ryszard Ganszyniec, „Honor i Ojczyzna”, Filomata, 435-436.

35 Tamże.
} 
W tekście „W zdrowym ciele zdrowe ciele”, który to tytuł jest parafrazą fragmentu z Iuvenalisa (Satyra X, w. 356: „ut sint mens sana in corpore sano”), Ignacy Wieniewski martwi się, że: „I dzisiaj przecież słyszymy utyskiwania o przewadze sportu nad rozwojem umysłowym młodzieży" ${ }^{\prime 3}$. Obecnie, w świecie komórek i smartfonów nie zagraża nikomu „przewaga sportu”, a jeśli już - to nie jest to sport realny, lecz wirtualny.

W innym numerze, także z 1939 roku, zamieszczono przemówienie prezesa Polskiej Akademii Umiejętności, profesora prawa UJ, Stanisława Wróblewskiego, wygłoszone pod koniec 1938 roku z okazji 350. rocznicy założenia Gimnazjum im. B. Nowodworskiego w Krakowie. Przemówienie nosiło tytuł: „Rola humanizmu w życiu" i - jak to było wówczas w zwyczaju - mówca odwołał się do mądrości antyku:

Rzymscy pontifices stworzyli zasadę, że dziedzictwo bierze się wraz z ciężarami. Te sacra cum hereditate coniuncta to kult przodków i dlatego każdy, kto wstępuje do tej szkoły, bierze na siebie obowiązek wzmożonego wysiłku, aby dorównał tym poprzednikom swoim, którzy pracą swoją najwięcej Polsce się przysłużyli ${ }^{37}$.

Nauki humanistyczne zaś mogą i powinny pomóc w tym, by jak najlepiej kształtowały się wzajemne relacje między przedstawicielami tego samego narodu, obywatelami państwa, a także między narodami.

\section{Podsumowanie}

„Człowiek jako istota godna wychowania” - to znakomite, aczkolwiek aspektowe i z pewnością niepełne określenie człowieka, doskonale opisujące grunt przedwojennej pedagogiki również dzisiaj może zostać wpisane w jej podstawy. Ten krótki, przeglądowy w istocie szkic, zawierający zaledwie kilka refleksów, czy raczej refleksji, nie rości sobie prawa do uogólnień, jakich wymaga dopracowana teoria. A jednak postrzeganie człowieka, jakie możemy wydobyć z migawkowych ujęć zawartych $\mathrm{w}$ tak bardzo różniących się stopniem i rodzajem specjalizacji tekstów pedagogicznych i filozoficznych, które wiąże wąska klamra czasowa, ich ukazanie się w roku 1939 w którymś z licznych ówczesnych czasopism, pozwala uchwycić zasadniczą różnicę tonu w porównaniu z pierwszymi dekadami wieku XXI. Wówczas mówiono o wychowaniu do człowieczeństwa w duchu najwyższej powagi. Bywało, że przybierano ton nazbyt pompatyczny, co nie przesądza o wartości treści, które mu towarzyszyły. Dzisiaj o człowieku rzadko kiedy mówi się w kontekście „nowoczesnej pedagogiki” jako o istocie duchowej. Z pewnością

\footnotetext{
36 Filomata, 317.

37 Tamże, 250.
} 
powodem tego są przyjęte założenia filozoficzne, mniej lub bardziej ukryte oraz uświadamiane, ale będące u podstaw pedagogicznych teorii. Istnieje oczywiście w pełni świadomy swoich korzeni filozoficznych nurt pedagogiki współczesnej, opartej na personalizmie chrześcijańskim. Ma on w Polsce swoje wielkie tradycje, które zostały ostatnio znacząco przybliżone współczesnym czytelnikom, nie tylko profesjonalnym pedagogom, dzięki takim pracom, jak monumentalna monografia Kierunki i koncepcje pedagogiki katolickiej w Polsce 1918-1939, gdzie między innymi została omówiona koncepcja wychowania personalistycznego, opracowana przez Karola Górskiego ${ }^{38}$.

W przywoływanej już tutaj uprzednio pracy Sławomira Sztobryna możemy przeczytać: „myśl pedagogiczna była i jest skorelowana z określonymi prądami w filozofii, co można przyjąć za zgodnymi w tym aspekcie poglądami Hessena, Nawroczyńskiego czy Sośnickiego, badania historyczne tej myśli w pewnym sensie będą badaniami filozofii wychowania" ${ }^{\text {39 }}$.

Przed wojną liczba wydawanych czasopism o treści pedagogicznej była imponująca ${ }^{40}$. Spośród nich były takie, które skupiały się na wybranych problemach określonych grup pedagogów i nauczycieli. Na przykład „Przegląd Pedagogiczny. Organ Towarzystwa Nauczycieli Szkół Średnich i Wyższych”, wydawany w Warszawie, w numerze z 4 II 1939 roku (pod redakcją Maksymiliana Tazbira) zawiera liczne informacje o poziomie wynagrodzeń nauczycieli, o negatywnych tendencjach w tym zakresie, o bezrobociu absolwentów szkół średnich, o strukturze społecznej uczniów etc. Oprócz tego pojawiły się projekty wyjścia z kryzysu, bardzo konkretne plany budowy nowych szkół w najbliższych miesiącach i latach, ale ich realizacja w związku $\mathrm{z}$ wojną została całkowicie uniemożliwiona, a w najlepszym wypadku oddalona na długie dziesięciolecia. Te wszystkie konkrety i - wydawałoby się - realistyczne i trzeźwe plany, oparte na finansowych obliczeniach zniweczyła wojna, a formacja, którą otrzymało tak wielu przedwojennych uczniów i uczennic, umożliwiła im potem nie tyle biologiczne przetrwanie, co godne życie aż do tragicznego i tak bardzo często przedwczesnego końca. Było to jednak życie naznaczone głębokim sensem i przepełnione ludzką godnością, bez względu na najtrudniejsze nawet okoliczności.

38 Janina Kostkiewicz, Kierunki i koncepcje pedagogiki, 372-392.

${ }^{39}$ Sławomir Sztobryn, „Wstęp”, 11-12.

${ }^{40} \mathrm{Na}$ stronie www.pow.lodz.pl/PRZEDWOJENNEPDF.pdf (dostęp: 20.05.2017) jest mowa o 140 polskich czasopismach pedagogicznych wydawanych w dwudziestoleciu międzywojennym; na tej stronie znajdują się informacje na temat 60 - między nimi nie ma czasopism wspominanych w tym szkicu. 
Streszczenie: Tematem artykułu są treści zawarte w wybranych polskich czasopismach, w których pojawiły się ówczesne poglądy dotyczące ideałów wychowawczych, roli tradycji $\mathrm{w}$ ich kształtowaniu, a także nowych tendencji w ówczesnej pedagogice. Pochodzą one z różnych obszarów badawczych, jak na przykład krzewiący pogłębioną znajomość antycznej tradycji w Polsce lwowski „Filomata”, „Pedagogium” - „czasopismo poświęcone psychologii nauczyciela i sposobom jego kształcenia”, „Pełnia Życia” - kwartalnik dla osób zakonnych czy wreszcie „Parametr” - specjalistyczny periodyk traktujący o nauczaniu matematyki, w którym także można odnaleźć refleksje ogólniejszej natury, związane z wymaganiami, jakie stawiano wówczas nauczycielom. Klamrą wiążącą ten wybór jest rok 1939, w którym ukazały się wszystkie przywołane tutaj teksty, oraz ich bezpośredni lub pośredni związek z wydarzeniami, które miały wkrótce radykalnie odmienić kulturowy obraz Europy i świata

Słowa kluczowe: przełom kulturowy, cezura wojny, ideał wychowawczy, psychologia a pedagogika, rola antycznej tradycji w wychowaniu.

\section{Bibliografia}

Elzenberg, Henryk. „Sprawozdania z książek: Charles Werner, La philosophie grecque, Paryż: Payot, 1938”. Przegląd Filozoficzny 42, z. 1 (1939): 110-111.

Ganszyniec, Ryszard. „Honor i Ojczyzna”. Filomata 107 (1939): 244-250.

Gumuła, Teresa. „Zadania wychowawcze szkoły na łamach czasopisma »Oświata i Wychowanie» (1929-1939)". Studia Pedagogiczne Akademii Świętokrzyskiej 15 (2005):183-194.

Jarowiecki, Jerzy. Hasło „Czasopisma pedagogiczne w Polsce”. W: Encyklopedia pedagogiczna, red. Wojciech Pomykało, 78-88. Warszawa: Fundacja „Innowacja”, 1993.

Jeleńska, Ludwika. „O celu lekcji”. Parametr 3, 1 (1939): 1-3.

Kostkiewicz, Janina. „Aksjologiczne podstawy katolickich koncepcji pedagogicznych”. W: Chrześcijańskie inspiracje w pedagogice, red. Janina Kostkiewicz, 13-43. Kraków: Wydawnictwo Uniwersytetu Jagiellońskiego, 2011.

Kostkiewicz, Janina. Kierunki i koncepcje pedagogiki katolickiej w Polsce 1918-1939. Kraków: Oficyna Wydawnicza „Impuls”, 2013.

Kroński, Tadeusz J. „Sprawozdania z książek: Jan B. Kozák, Veda a duch, wyd. Jan Laichter, Praha 1938”. Przegląd Filozoficzny 42, 1 (1939): 111-112.

Lewowicki, Tadeusz. „Pedagogika a demokracja - refleksje nad kondycją pedagogiki”. W: Demokracja a oświata, kształcenie i wychowanie. Materiały z II Ogólnopolskiego Zjazdu Pedagogicznego, red. Henryka Kwiatkowska, Zbigniew Kwieciński, 31-44. Toruń: Polskie Towarzystwo Pedagogiczne, 1996.

Nowaczyk, Stanisław. „Rola nauczycielstwa w naukowym organizowaniu pracy szkolnej (Materiały do dyskusyj i referatów)". Pedeagogium. Czasopismo poświęcone psychologii nauczyciela i sposobom jego ksztatcenia 1, 2/3 (1938/1939): 117-132.

Pirożyński Marian, Rocznik statystyczny Kościoła katolickiego w Polsce. Lublin: Uniwersytet, 1938.

Pirożyński Marian, Zakony żeńskie w Polsce. Lublin: Uniwersytet, 1935.

Reale, Giovanni. „Mądrość antyczna lekarstwem na zło nękające współczesnego człowieka”. W: Giovanni Reale, Doktor Honoris causa Katolickiego Uniwersytetu Lubelskiego, red. Agnieszka Bieńkowska, 13-41. Lublin: Wydawnictwo KUL, 2001.

Schwarz, Jan. „Czy cechy dobrego nauczyciela są wykształcalne?”. Pedeagogium. Czasopismo poświęcone psychologii nauczyciela i sposobom jego kształcenia 1, 2/3 (1938/1939): 101-116. 
Sztobryn, Sławomir. Polskie badania nad myśla pedagogiczna w latach 1900-1939 w świetle czasopiśmiennictwa. Ujęcie metahistoryczne. Łódź: Wydawnictwo Uniwersytetu Łódzkiego, 2000.

Wróblewki, Stanisław. „Rola humanizmu w życiu”. Filomata 107 (1939): 244-250.

\section{Netografia}

www.pow.lodz.pl/PRZEDWOJENNEPDF.pdf (dostęp: 20.05.2017). 
